\title{
Final Properties Factices and Binding Constitutional Court Decisions by Adding Judicial Order Law Instruments in Testing the Law of the Basic Law
}

\author{
Salsabilla Akbar $^{1 *}$, Retno Saraswati ${ }^{2}$, Fifiana Wisnaeni $^{3}$ \\ \{salsabillakbar@gmail.com ${ }^{1 *}$, retno.saraswati@live.undip.ac.id ${ }^{2}$, fifiana.undip@gmail.com ${ }^{3}$ \}
}

Fakultas Hukum, Universitas Diponegoro, Jl. Prof. H. Soedarto, S.H., Semarang, Indonesia 50275 1,2,3

\begin{abstract}
The Constitutional Court as an institution that has the authority to examine the Law against the Basic Law. It has the nature of a final and binding decision, however, in reality, the facts show that the final and binding decision is often not responded positively by the organ of the state administrators so that the decision cannot be implemented. The purpose of this study is to explain the legal facticity of the nature of the Constitutional Court's ruling, and explain and analyze the importance of adding judicial order legal instruments to the ruling of the Constitutional Court in Indonesia. This study uses a normative juridical approach with descriptive analytics dy to obtain secondary data. Data analysis techniques uses a qualitative analysis method that is obtained, selected, and arranged systematically. The conclusion of this research is the decision of the Constitutional Court has the nature of a final and binding decision that has been regulated in Article 24C paragraph (1) of the 1945 Constitution of the Republic of Indonesia which is reaffirmed in Article 10 paragraph (1) letters a through d of the Law Number 8 of 2011 concerning Amendment to Law Number 24 of 2003 concerning the Constitutional Court. The existence of legal facticity from the nature of the Constitutional Court's ruling cannot be implemented due to a shift in the Constitutional Court's ruling variant, resulting in the need for further action by the state administrators so that the ruling can be implemented. The problem of the inaccuracy of the decision is due to the absence of a follow-up of the government organ that makes the Constitutional Court requiring the addition of a judicial order legal instrument in the Constitutional Court's decision on judicial review of the Basic Law as one of the efforts to resolve the problem in the Constitutional Court decision.
\end{abstract}

Keywords: Nature of Decision of the Constitutional Court, Legal Facticity, Judicial Order.

\section{Introduction}

Indonesia is a constitutional state based on the 1945 Constitution of the Republic of Indonesia (1945 Constitution) in article 1 paragraph (3). In understanding the rule of law, the law that holds the highest command in the administration of the state, [1] in this context the entire system of state administration must be based on the constitution so that the administration of the state delegated to state organs runs according to the legal corridor which is subject to the constitution.

The 1945 Constitution of the Republic of Indonesia guarantees the rights of its citizens through the authority possessed by the Constitutional Court (MK). One of which is the 
authority to examine the laws against the 1945 Constitution of the Republic of Indonesia. General (erga ormes) based on the facticity of the law contained in article $24 \mathrm{C}$ paragraph (1) of the 1945 Constitution of the Republic of Indonesia. Legal facticity is a condition that seeks to guarantee legal certainty based solely on the formulation of the law itself.

Based on the legal fact that there is a final and binding power to the Constitutional Court's decision is something that cannot be denied, in reality however, the fact shows that the Constitutional Court's decision is often not responded positively by state administrators in the form of noncompliance with decisions. This is also evidenced by the research of SETARA Institute research in 2016 which showed that there were 19 decisions have not been followed up by state organs.

Non-compliance with the organs of state administrators occurs along with the development of the Constitutional Court's decision which causes the development of the implementation of the decision, namely:

a) Decision of the Constitutional Court that can be directly executed (Self Implementing)

b) Decisions of the Constitutional Court which cannot be directly executed (Non-Self Implementing)

The lack of compliance of the organs of state administrators towards the Constitutional Court's decision shows that there are implementation problems in the Constitutional Court's decision, especially on the Constitutional Court's decision which requires follow-up. So, a judicial order legal instrument is needed so that there is clarity of action that needs to be carried out by the state's organizing organ after the Constitutional Court's decision.

Based on the description above, the problem formulation that can be compiled consists of:

1. How is the implementation of the facticity final and binding on the Constitutional Court's decision in Indonesia?

2. What is the importance of adding a judicial order legal instrument to the Constitutional Court's decision in judicial review of the constitution?

\section{Method}

The method used in this research is the normative juridical approach. According to Soerjono Soekanto, the normative juridical approach is legal research carried out by examining literature material or secondary data as a basic material to be investigated by conducting a search of the regulations and literature relating to the problem under study [2]. This normative juridical approach begins by reviewing the laws and regulations and other regulations and is expected to provide a real and systematic picture and answers to these problems.

\subsection{Research Specification}

The research specification used is analytical descriptive, which is the research method used aimed at describing a problem in a particular area or at certain times. Researchers try to express the facts as complete as it is [3]. Descriptive research aims to systematically and accurately describe facts and characteristics about the population or regarding a particular field. 


\subsection{Method of collecting data}

The method of approach that the authors take in writing law is normative juridical, so that the data used are secondary data. Secondary data is data obtained by a researcher indirectly from the source (research object), but through other sources. Legal material is the most important part in legal research. Without legal material, it would not be possible to find answers to the issues raised [3].

Legal material taken by researchers consisted of primary legal materials:

a. NRI 1945 Constitution;

b. Law Number 30 Of 2002 concerning the Corruption Eradication Commission;

c. Law Number 5 Of 2010 concerning Amendments to Law Number 22 Of 2002 concerning Clemency;

d. Law Number 8 of 2011 concerning Amendment to Law Number 24 of 2003 concerning MK

e. Law Number 12 of 2011 concerning Formation of Regulations and Regulations;

f. MK Decision Number 34/PUU-XI/2013 concerning Testing of Law Number 8 of 1981;

g. MK Decision Number 107/PUU-XIII/2015 concerning Testing of Law Number 5 Of 2010 concerning Amendment to Law Number 22 Of 2002.

Secondary legal materials consist of:

a. Books

b. Journals

c. Dissertation, Thesis, and Legal Thesis

d. Paper

Secondary legal materials consist of:

a. Indonesia Dictionary

b. Black Law Dictionary

\section{Results and Discussion}

\subsection{Legal Facticity of Final and binding nature of the Constitutional Court's Decision}

Legal facticity is defined as a condition that seeks to guarantee legal certainty based on the formulation of the law itself [4]. The Constitutional Court through article $24 \mathrm{C}$ paragraph (1) of the 1945 Constitution of the Republic of Indonesia and reaffirmed in article 10 paragraph (1) letters a through d of Law Number 8 of 2011 concerning Amendments to Law Number 24 of 2003 concerning the Constitutional Court, [5], [6], has legal facts that contain its authorities along with provisions regarding the final nature and binding decisions of the Constitutional Court. Based on the legality of the law the Constitutional Court's, the decision can be said erga omnes, which according to Bargir Manan, it is a decision whose consequences apply to all cases that contain similarities that may occur in the future, so when the legislation is declared invalid because it contradicts the 1945 Constitution then it becomes null and void for everyone [7]. The occurrence of developments in the Constitutional Court's 
decision, namely from the decision rejecting, unacceptable, and granted to be increased to conditional constitutional decisions, conditional unconstitutional, postponement of enforcement, until the formulation of new norms makes the validity of the decision not only as a direct decision can be implemented without having to make new regulations or changes to the conditional (Self Implementing) and there are also those who need further regulation (Non-Self Implementing) [8]. The validity of Non-Self Implementing decisions causes problems in the factual nature of the law and is binding on the Constitutional Court's decision when it is not followed up by state organs such as:

a. Decision Number 34/PUU-XI/2013 concerning Testing of Law Number 8 of 1981 concerning Criminal Procedure Law to the 1945 Constitution of the Republic of Indonesia, where in this decision the Court granted the MK the request for retesting (PK) can be done more than once but in in fact there was a non-compliance by the Supreme Court by issuing a Supreme Court Circular which contradicted the contents of the Constitutional Court's decision.

b. Decision Number 107/PUU-XIII/2015 concerning Testing of Law Number 5 Of 2010 concerning Amendment to Law Number 22 Of 2002 Regarding Clemency in which the Constitutional Court principally issued a decision granting the request that the time for filing a request for clemency must be returned to Law Number 22 of 2002, but until now there has been no changes made by the legislature to the decision.

Both decisions are examples of decisions that require follow-up (Non-Self Implementing). This problem requires awareness of the harmonization and obedience of the parties in the decision so that the Constitutional Court's decision can be carried out in accordance with the fact of the law of the nature of the final and binding that has been regulated in the 1945 Constitution of the Republic of Indonesia. to the Court and the spirit of the birth of the Court.

\subsection{The Importance of Adding Judicial Order Legal Instruments in the Judicial Review of the Basic Laws}

\section{Judicial Order}

The Constitutional Court's decision is a legal product whose consequences are felt by all citizens, this certainly needs to be supported with maximum implementation. Decisions of the Constitutional Court need to get guarantees so that each of its decisions can be carried out. This guarantee can be realized through the addition of a judicial order legal instrument intended as a legal order given by the Constitutional Court through its decision to force related institutions to take the necessary follow-up according to the Constitutional Court's decision.

\section{Application of Judicial Orders in Other Countries}

The application of a judicial order was carried out by the Constitutional Court of the Federal Republic of Germany (FCC) in August 1995 which required the statutory organs to comply with the FCC's constitutional interpretation [9]. Another case also occurred in the United States where the Supreme Court contained a judicial order in its decision. Based on the implementation problems in Germany and the United States, it cannot be denied that this might happen in Indonesia. Therefore, it can be used as a solution in suppressing the problem of the Court's decision to implement the judicial order.

\section{Application of the Judicial Order in Indonesia}


The Constitutional Court in its legal fact has not yet regulated the legal instrument of the judicial order. However, if observed, the Constitutional Court would have issued a decision that adapted the concept of a judicial order, namely the decision of the Constitutional Court Number 102/PUU-VII/2009 dated July 6, 2009 concerning Testing of Law Number 42 of 2008 concerning Election of President and Vice President, the concept of judicial order lies in the decision in the opinion section, which states:

"[3.23] Considering whereas before giving a Decision on the constitutionality of the articles petitioned for review, so that on the one hand it does not cause impairment of the citizens' constitutional rights and on the other hand does not violate the provisions of the applicable laws and regulations, the Court needs to order the General Election Commission ( KPU) to further regulate the technical implementation of the use of voting rights for Indonesian citizens who are not registered in the DPT with the following guidelines: ..."

In these considerations, there is a clause "The Court Needs to Order the General Election Commission (KPU)" in which in this case the Republic of Indonesia has appointed the KPU institution to follow up on the verdict in this case. The designation of the institution in this ruling reflects the use of judicial order in the ruling of the Republic of Indonesia. This decision has also been followed up by related institutions with the inclusion of this RI Constitutional Court ruling in Law Number 8 of 2012 concerning General Elections of Members of the People's Legislative Council, the Regional Representative Council, and the Regional People's Representative Council. Follow-up carried out by related institutions is a form of maximum implementation, indicating that indeed the addition of judicial order legal instruments inherent in the Constitutional Court's decision in testing the law against the 1945 Constitution of Indonesia in Indonesia can be a solution to suppress the problem of the implementation of the Constitutional Court's decision.

\section{Conclusion}

Based on the studies conducted in this legal research, there are several things that can be drawn as conclusions, including:

1. The legal fact of final nature and binding decisions of the Constitutional Court contained in Article 24C paragraph (1) of the 1945 Constitution of the Republic of Indonesia which is reaffirmed in Article 10 paragraph (1) letters a to d of Law Number 8 of 2011 concerning Amendment to Law Number 24 of 2003 concerning the Constitutional Court. Therefore, every decision issued by the Constitutional Court applies to all citizens, and does not escape the organs of state administrators. There is no further legal remedies can be made, however, in reality, the facts show that the final decision and binding are often not responded positively by the organ of the state administration so that the decision is not implemented.

2. A judicial order legal instrument is needed because:

a. The need for legal certainty regarding the implementation of the decisions of the Constitutional Court, especially on decisions that are non-self implementing. 
b. The application of judicial order legal instruments has been applied by other countries, and is proven to be able to overcome the problem of implementing the decision.

c. Indonesia once applied the concept of a judicial order to Decision Number 102/PUU-VII/2009 issued by the Constitutional Court. 


\section{References}

[1] J. Asshidiqie, Konstitusi dan Konstitusionalisme Indonesia. Jakarta: Sinar Grafika, 2014.

[2] S. S. and S. Mamudji, Penelitian Hukum Normatif: Suatu Tinjauan Singkat. Jakarta: Rajawali Pers, 2001.

[3] Suteki and G. Taufani, Metodologi Penelitian Hukum: Filsafat, Teori, dan Praktik. Depok: Rajawali Pers, 2004.

[4] F. L. Soeroso, “PEMBANGKANGAN' TERHADAP PUTUSAN MAHKAMAH KONSTITUSI,” J. Yudisial, vol. 6, no. 3, pp. 227-249, 2013.

[5] Law Number 8 of 2011 concerning Amendments to Law Number 24 of 2003 concerning the Constitutional Court. .

[6] A. Roestandi, Mahkamah Konstitusi dalam Tanya Jawab. Jakarta: Sekretariat Jenderal dan Kepaniteraan Mahkamah Konstitusi Republik Indonesia, 2006.

[7] B. Suhariyanto, "Masalah Eksekutabilitas Putusan Mahkamah Konstitusi oleh Mahkamah Agung," J. Konstitusi, vol. 13, no. 1, pp. 171-190, 2016.

[8] M. A. Safa'at, "Kekuatan Mengikat dan Pelaksanaan Putusan MK," 2019. [Online]. Available: $\quad$ http://safaat.lecture.ub.ac.id/files/2014/03/Kekuatan-Mengikat-danPelaksanaan-Putusan-MK.pdf. [Accessed: 28-Feb-2019].

[9] Bachtiar, Problematika Implementasi Putusan Mahkamah Konstitusi Pada Pengujian UU Terhadap UUD. Jakarta: Raih Asa Sukses, 2015. 